\title{
ANALISIS PENERAPAN GOOD GOVERNANCE BISNIS SYARIAH DALAM MENCAPAI MAQASHID SYARIAH PADA BANK UMUM SYARIAH DI INDONESIA
}

\author{
Fredy Dwi Herlyanto \\ Universitas Muhammadiyah Malang \\ Jl. Raya Tlogomas No. 246 Malang, 65144, Indonesia \\ e-mail:fre4hun@gmail.com
}

\section{Abstract}

This study aims to analyze the application of good governance business sharia in achieving maqashid sharia in Islamic sharia banks in Indonesia. To analyze the application of sharia business governance, namely by using content analysis that refers to the national governance policy committee as many as 47 indicators. To analyze the achievement of maqashid sharia using financial ratios that reflect the three components of maqashid sharia, namely education, justice, and benefit. The results of this study, namely the application of sharia business governance in the amount of 93\% has not had an impact on the achievement of overall sharia maqashid during 2015-2017. If viewed based on each goal, the implementation of sharia business governance will have an impact on achieving creating justice.

Keywords: Islamic Sharia Bank, good governance business sharia, maqashid sharia

\section{Abstrak}

Penelitian ini bertujuan untuk menganalisis penerapan bisnis good governance syariah dalam mencapai maqashid syariah di bank syariah syariah di Indonesia. Untuk menganalisis penerapan tata kelola bisnis syariah, yaitu dengan menggunakan analisis isi yang mengacu pada komite kebijakan tata kelola nasional sebanyak 47 indikator. Untuk menganalisis pencapaian maqashid syariah menggunakan rasio keuangan yang mencerminkan tiga komponen maqashid syariah, yaitu pendidikan, keadilan, dan manfaat. Hasil penelitian ini, yaitu penerapan tata kelola bisnis syariah dalam jumlah 93\% belum berdampak pada pencapaian maqashid syariah secara keseluruhan selama 2015-2017. Jika dilihat berdasarkan pada masing-masing tujuan, penerapan tata kelola bisnis syariah akan berdampak pada tercapainya keadilan.

Kata kunci: Bank Syariah, tata kelola bisnis syariah, maqashid syariah

\section{PENDAHULUAN}

Pembahasan mengenai good corporate governance berawal dari munculnya kasus yang menimpa Enron yang mengalami kegagalan dalam mengelola perusahaannya sehingga terjadi banyak kecurangan dalam kegiatan operasinya (Kelly, 2003). Beberapa perusahaan di Indonesia dalam menerapkan good corporate governance masih tertinggal. Dikutip dalam berita CNN Indonesia yang 
Fredy Dwi Herlyanto: Analisis Penerapan Good Governance Bisnis Syariah Dalam Mencapai Maqashid Syariah pada Bank Umum Syariah di Indonesia

ditulis oleh Primadhyta (2017), Ketua Dewan Komisaris OJK Wimboh Santoso mengungkapkan hanya ada dua emiten dari Indonesia yang masuk 50 emiten terbaik dalam praktik GCG di ASEAN dalam ajang ASEAN Corporate Governance Award 2015 di Manila, yaitu PT Bank Danamon Tbk dan PT Bank CIMB Niaga Tbk.

Untuk mendorong kegiatan perbankan syariah menerapkan prinsipprinsip GCG dan tangguh dalam memenuhi prinsip syariah. Bank Indonesia mengeluarkan Peraturan Bank Indonesia No. 11/33/PBI/2009 tentang pelaksanaan Good Corporate Governance bagi bank umum syariah dan unit usaha syariah. Pemerintah melalui Komite Nasional Kebijakan Governance (KNKG) tahun 2011 membentuk tim penyusun good govenance bisnis syariah (GGBS) beranggotakan masyarakat ekonomi syariah, DSN MUI, dan Bank Indonesia (Holili, 2017). GGBS merupakan elemen penting untuk mempertahankan pertumbuhan dan keberlanjutan usaha, karena dengan menerapkan GGBS yang sesuai dengan ketentuan syariah akan menumbuhkan budaya kerja yang sehat disegala bidang sehingga membuat investor puas terhadap kinerja dan nilai perusahaan (Meilani, 2015).

Selain berkewajiban untuk menerapkan GGBS, bank syariah juga penting untuk memperhatikan kinerjanya yang sesuai dengan tujuan utama yaitu kesejahteraan dunia dan akhirat. Pengukuran kinerja pada bank syariah tidak hanya terdiri dari aspek keuangan saja, tetapi juga dari aspek non keuangan yang tercermin dalam maqashid syariah (Holili, 2017). Selama ini, dalam menilai kinerja bank syariah maupun bank konvensional tidak terdapat perbedaan, padahal kedua bank tersebut memiliki kegiatan operasi yang berbeda baik prinsip maupun filosofi (Mohammed dan Taib, 2015). Karena terdapat perbedaan tersebut, maka untuk mengukur kinerja bank syariah dalam mencapai tujuannya akan lebih tepat jika menggunakan pendekatan maqashidsyariah (Kholid dan Bachtiar, 2015). Para stakeholder menginginkan bank syariah untuk menerapkan good governance bisnis syariah serta mencapai maqashid syariah, maka dibutuhkan komitmen yang kuat untuk mengelola organisasi dengan baik (Kelly, 2003).

Bisnis yang berlandaskan pada ketentuan syariah merupakan suatu upaya untuk mempertahankan keberlangsungan usaha dengan terimplementasinya 
Fredy Dwi Herlyanto: Analisis Penerapan Good Governance Bisnis Syariah Dalam Mencapai Maqashid Syariah pada Bank Umum Syariah di Indonesia

akhlaqul karimah disetiap aspek kegiatan usaha. Kegiatan bisnis yang dipandu dengan akhlak yang baik memiliki tujuan agar terciptanya rahmatan lil 'alamin yaitu dengan tercapainya maqashid syariah. Oleh karena itu, peneliti tertarik untuk melakukan analisis penerapan good governance bisnis syariah dalam mencapai maqashid syariah pada bank umum syariah di Indonesia dengan menggunakan periode pengamatan selama tahun 2015-2017.

\section{KAJIAN PUSTAKA}

\section{Maqashid Syariah}

Secara bahasa, kata maqashid syariah terdiri atas dua kata maqashid yang berarti kesengajaan atau tujuan, dan syariah berarti jalan menuju sumber air. Jalan menuju air dapat dikatakan sebagai jalan kearah sumber pokok kehidupan (Muzlifah, 2013). Maqashid syariah memiliki fungsi dalam melakukan dua hal penting, yaitu tahsil, yakni mengamankan manfaat, dan ibqa yaitu mencegah kerusakan atau cedera. Maqashid syariah ialah tujuan tertinggi yang digariskan oleh Allah swt sebagai tujuan utama dari syariah yaitu sebagai pelestari kehidupan, pelestari agama, pelestari keluarga, pelestarian karakter dan pikiran manusia, serta pelestarian kekayaan (Muchlis dan Sukirman, 2016). Tata kelola perusahaan yang baik dan sesuai dengan ketentuan syariah merupakan upaya untuk mempertahankan keberlangsungan usaha dengan mengimplementasikan akhlaqul karimah bertujuan agar terciptanya rahmatan lil 'alamin dengan tercapainya tujuan syariah (maqashid syariah).

\section{Good Governance Bisnis Syariah}

Penelitian mengenai dampak pelaksanaan good governance bisnis syariah dilakukan oleh beberapa peneliti. Novrianda dan Shar (2016) menganalisis hubungan antara penerapan GCG dalam hubungannya dengan kinerja keuangan pada Bank BRI Syariah. Didapatkan hasil, bahwa hubungan penerapan GCG dengan kinerja keuangan pada PT Bank BRI Syariah sudah berjalan baik dengan rata-rata pernyataan responden yaitu 3,77 termasuk pada interval rata-rata 3,404,19 yang termasuk kriteria baik dan mampu untuk meningkatkan ROA perusahaan sebesar 0,76\%. Salim (2018) juga melakukan penelitian mengenai perbedaan kinerja keuangan sebelum dan sesudah penerapan good corporate governance pada Bank Syariah Mandiri. Didapatkan hasil, bahwa penerapan good 
Fredy Dwi Herlyanto: Analisis Penerapan Good Governance Bisnis Syariah Dalam Mencapai Maqashid Syariah pada Bank Umum Syariah di Indonesia

corporate governance tidak memberikan dampak terhadap kinerja perusahaan jika dilihat dari rasio profitabilitas dan non performing financing, tetapi penerapan good corporate governance akan memberikan dampak pada kinerja perusahaan jika dilihat dari rasio likuiditas serta solvabilitas.

Holili (2017)menganalisis penerapan GGBS dan pencapaian kinerja perbankan syariah di Indonesia ditinjau dari maqashidsyariahserta profitabilitas. Didapatkan hasil, bahwa penerapan GGBS pada bank syariah pada tahun 20132015 mengalami peningkatan setiap tahunnya dengan rata-rata pengungkapan berturut-turut $70,56 \%, 72,51 \%$ dan $73,81 \%$. Rata-rata pencapaian kinerja bank umum syariah dilihat dari pencapaian maqashidsyariah selama tahun 2013-2015 mencapai $16,20 \%$. Sedangkan bila ditinjau dari rata-rata kinerja profitabilitas yang diukur menggunakan ROA, ROE dan PER selama tahun 2015-2017,rata-rata profitabilitas berturut-turut 2,92\%,60,38\% dan 16,13\%. Febriadi (2017) meneliti tentang aplikasi maqashid syariah di industri perbankan syariah. Didapatkan hasil, bahwa pengaplikasian maqashid syariah pada bank syariah tercermin dalam kegiatan operasional serta produk dan layanan yang diberikan oleh bank sebagai wujud kontribusi bank syariah untuk mencapai maqashidsyariah.

Antonio et al. (2012) membandingkan penerapan maqashid index di Indonesia dan Jordania. Didapatkan hasil bahwa maqashid index pada industri perbankan Indonesia lebih baik dibandingkan dengan Jordania. Penelitian serupa dilakukan oleh Mutia dan Musfirah (2017) tentang pendekatan maqashidsyariah index sebagai pengukuran kinerja perbankan syariah di Asia Tenggara. Didapatkan hasil bahwa negara Indonesia memiliki performa kinerja maqashid syariah terbaik dengan rata-rata skor 46,22\%. diikuti Malaysia dengan 43,15\%, Brunei Darussalam 37,54\%, Thailand 17,51\% dan Filipina 1,12\%.

Penelitian mengenai pencapaian maqashid syariah dilakukan oleh Jumansyah dan Syafei (2013), tentang penerapan good governance bisnis syariah dan pencapaian maqashid syariah Bank Syariah di Indonesia, didapatkan hasil, bahwa penerapan good governance bisnis syariah selama tahun 2009-2011 yang dihitung berdasarkan item good governance bisnis syariah yang diungkapkan, Bank Syariah Mandiri mengungkapkan rata-rata sebesar 92,06\% atau sebanyak 39 dari 42 item dan lebih tinggi dibandingkan dengan Bank Muamalat Indonesia sebesar 78,57\% atau sebanyak 33 dari 42 item. Bila dilihat dari pencapaian 
Fredy Dwi Herlyanto: Analisis Penerapan Good Governance Bisnis Syariah Dalam Mencapai Maqashid Syariah pada Bank Umum Syariah di Indonesia

maqashidsyariaholeh Bank Muamalat Indonesia dan Bank Syariah Mandiri selama tahun 2009-2011, rata-rata pencapaian kedua bank tersebut relatif kecil. Rata-rata pencapaian maqashidsyariah oleh Bank Muamalat Indonesia selama tahun 2009-2011 hanya sebesar 22,49\%, sedangkan untuk Bank Syariah Mandiri sebesar $21,07 \%$.

\section{METODE}

Penelitian ini merupakan penelitian deskriptif, dimana penelitian bertujuan uuntuk menganalisis penerapan good governance business syariah (GGBS) dalam mencapai maqashid syariah pada bank umum syariah di Indonesia. Penelitian ini menggunakan objek sebanyak sembilan bank umum syariah yang menjalankan kegiatan bisnisnya di Indonesia selama tahun 2015-2017. Jenis data yang digunakan merupakan data sekunder, yang didapatkan secara dokumentasi melalui website resmi masing-masing bank umum syariah. Unit analisis pada penelitian ini yaitu good governance bisnis syariah dan pencapaian maqashid syariah.

Untuk menganalisis penerapan GGBS menggunakan content analysis. Kategori/item GGBS yang digunakan dalam penelitian ini yaitu mengacu pada PBI No. 11/33/PBI/2009 dan KNKG tahun 2011 sebanyak 47 indikator. Peneliti melakukan penulusuran data secara manual pada annual report bank umum syariah. Setelah mendapatkan item-item GGBS, peneliti memberikan angka satu (1) bila item tersebut diungkapkan, dan angka nol (0) bila tidak diungkapkan. Hasil dari pengkodean tersebut kemudian dimasukkan kedalam tabel dan dijadikan dalam bentuk prosentase.

Untuk mengukur pencapaian kinerja syariah (maqashid syariah) pada penelitian ini yaitu dengan menggunakan pengukuran yang dikembangkan oleh Mohammed dan Razak (2008) mengacu pada pengukuran Abu Zahrah tahun 1997. Pengukuran kinerja maqashidsyariah dikelompokkan menjadi tiga elemen, yaitu (1) Tahdib al-Fard (mendidik individu); (2) Iqamah Al-Adl (menegakkan keadilan); dan (3) Jaib al-Maslahah (Meningkatkan kesejahteraan). 
Fredy Dwi Herlyanto: Analisis Penerapan Good Governance Bisnis Syariah Dalam Mencapai Maqashid Syariah pada Bank Umum Syariah di Indonesia

Untuk mengukur pencapaian maqashid syariah menggunakan rasio-rasio keuangan yang dapat dilihat pada tabel berikut:

Tabel 1. Rasio Pengukuran Kinerja Maqashid Syariah

\begin{tabular}{|c|c|c|c|}
\hline $\begin{array}{l}\text { Konsep } \\
\text { (tujuan) }\end{array}$ & Dimensi & Elemen & Rasio Kinerja \\
\hline \multirow{5}{*}{$\begin{array}{l}\text { Mendidik } \\
\text { Individu } \\
\text { Menegakkan } \\
\text { Keadilan }\end{array}$} & \multirow{2}{*}{$\begin{array}{l}\text { D.1 Kemajuan } \\
\text { Pengetahuan }\end{array}$} & $\begin{array}{l}\text { E.1 Bantuan } \\
\text { Pendidikan }\end{array}$ & $\begin{array}{l}\text { R.1 Bantuan Pendidikan } \\
\text { / Total Biaya }\end{array}$ \\
\hline & & E.2 Penelitian & $\begin{array}{l}\text { R.2 Biaya Penelitian / } \\
\text { Total Biaya }\end{array}$ \\
\hline & $\begin{array}{l}\text { D.2 Peningkatan } \\
\text { Keahlian }\end{array}$ & E.3 Pelatihan & $\begin{array}{c}\text { R.3 Biaya Pelatihan / } \\
\text { Total Biaya }\end{array}$ \\
\hline & $\begin{array}{l}\text { D.3 Meningkatkan } \\
\text { Kesadaran } \\
\text { Akan Bank } \\
\text { Syariah Islam }\end{array}$ & E.4 Publikasi & $\begin{array}{c}\text { R.4 Biaya Promosi / } \\
\text { Total Biaya }\end{array}$ \\
\hline & $\begin{array}{l}\text { D.4 Kontrak yang } \\
\text { Adil }\end{array}$ & E.5Fair Return & $\begin{array}{l}\text { R.5 Bagi hasil belum } \\
\text { dibagi / } \\
\text { Pendapatan }\end{array}$ \\
\hline \multirow{2}{*}{$\begin{array}{l}\text { Menegakkan } \\
\text { Keadilan }\end{array}$} & $\begin{array}{c}\text { D.5 Jasa dan Produk } \\
\text { yang } \\
\text { Terjangkau }\end{array}$ & $\begin{array}{r}\text { E.6 Distribusi } \\
\text { Fungsional }\end{array}$ & $\begin{array}{l}\text { R.6 Mudharabah dan } \\
\text { Musyarakah / Total } \\
\text { Pembiayaan }\end{array}$ \\
\hline & $\begin{array}{c}\text { D.6 Menghilangkan } \\
\text { ketidakadilan }\end{array}$ & $\begin{array}{l}\text { E.7 Produk Bebas } \\
\text { Bunga }\end{array}$ & $\begin{array}{l}\text { R.7 Pendapatan Bebas } \\
\text { Bunga / Total } \\
\text { Pendapatan }\end{array}$ \\
\hline \multirow{3}{*}{$\begin{array}{l}\text { Kepentingan } \\
\text { Publik }\end{array}$} & D.7 Profitabilitas & E.8 Rasio Laba & $\begin{array}{l}\text { R.8 Laba bersih / Total } \\
\text { Aset }\end{array}$ \\
\hline & $\begin{array}{l}\text { D.8 Distribusi } \\
\text { Pendapatan } \\
\text { dan } \\
\text { Kesejahteraan }\end{array}$ & $\begin{array}{l}\text { E.9 Pendapatan } \\
\text { Individu }\end{array}$ & R.9 Zakat / Aset bersih \\
\hline & $\begin{array}{l}\text { D.9 Investasi dalam } \\
\text { Sektor Riil }\end{array}$ & $\begin{array}{l}\text { E.10 Rasio } \\
\text { investasi di } \\
\text { Sektor Riil }\end{array}$ & $\begin{array}{l}\text { R.10 Total Investasi } \\
\text { Sektor Riil/ Total } \\
\text { Investasi }\end{array}$ \\
\hline
\end{tabular}

Sumber: Mohammed dan Razak (2008)

Untuk menganalisis penerapan good governance bisnis syariah peneliti membandingkan prosentase pengungkapan GGBS dengan pencapaian maqashid syariah pada bank umum syariah di Indonesia. Kemudian peneliti melakukan verifikasi untuk mendapatkan bobot dari masing-masing maqashid syariah dengan mengalikan masing-masing bobot dengan hasil dari rasio keuangan. 
Fredy Dwi Herlyanto: Analisis Penerapan Good Governance Bisnis Syariah Dalam Mencapai Maqashid Syariah pada Bank Umum Syariah di Indonesia

Bobot masing-masing maqashid syariah dapat dilihat pada tabel berikut:

Tabel 2. Bobot Masing-Masing Tujuan dan Elemen

\begin{tabular}{|c|c|c|c|}
\hline Tujuan & $\begin{array}{c}\text { Bobot Tujuan } \\
(\%)\end{array}$ & Elemen & $\begin{array}{c}\text { Bobot Elemen } \\
(\%)\end{array}$ \\
\hline \multirow{5}{*}{ T.1 Pendidikan } & \multirow{5}{*}{30} & $\begin{array}{l}\text { E.1 Bantuan } \\
\text { Pendidikan }\end{array}$ & 24 \\
\hline & & E.2 Penelitian & 27 \\
\hline & & E.3 Training & 26 \\
\hline & & E.4 Publikasi & 23 \\
\hline & & Total & 100 \\
\hline \multirow{4}{*}{ T.2 Keadilan } & \multirow{4}{*}{41} & E.5Fair Return & 30 \\
\hline & & E.6 Fair Price & 32 \\
\hline & & $\begin{array}{c}\text { E.7 Produk bebas } \\
\text { bunga }\end{array}$ & 38 \\
\hline & & Total & 100 \\
\hline \multirow{4}{*}{ T.3 Kesejahteraan } & \multirow{4}{*}{29} & E.8 Rasio Laba & 33 \\
\hline & & $\begin{array}{l}\text { E.9 Transfer } \\
\text { Pendapatan }\end{array}$ & 30 \\
\hline & & $\begin{array}{c}\text { E.10 Rasio investasi } \\
\text { sektor riil }\end{array}$ & 37 \\
\hline & & Total & 100 \\
\hline Total & 100 & & \\
\hline
\end{tabular}

Sumber: Mohammed dan Razak (2008)

\section{HASIL DAN PEMBAHASAN}

Analisis yang dilakukan untuk menganalisis penerapan GGBS yaitu dengan menggunakan content analysis. Langkah pertama untuk menganalisis yaitu dengan membaca dan mencari item-item GGBS pada annual report bank umum syariah selama tahun 2015-2017 sebanyak sembilan bank umum syariah, yang dikumpulkan menggunakan teknik dokumentasi dari website resmi masingmasing bank umum syariah. Setelah item-item dari GGBS didapatkan, kemudian memberikan kode satu (1), jika item tersebut diungkapkan, dan (0) jika item tersebut tidak diungkapkan. Kemudian memasukkannya kedalam tabel untuk mendapatkan prosentase pengungkapan item GGBS, kemudian dihitung ratarata pengungkapan dari item GGBS dari sembilan bank umum syariah tersebut selama periode pengamatan. 
Fredy Dwi Herlyanto: Analisis Penerapan Good Governance Bisnis Syariah Dalam Mencapai Maqashid Syariah pada Bank Umum Syariah di Indonesia

Berikut merupakan rata-rata pengungkapan GGBS pada bank umum syariah di Indonesia selama tahun 2015-2017:

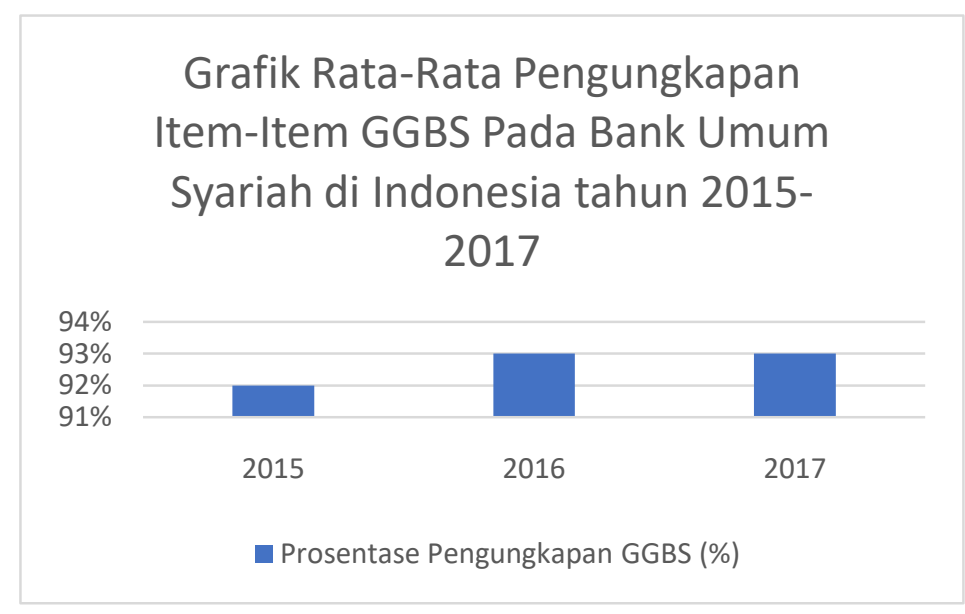

\section{Gambar 1. Rata-Rata Pengungkapan GGBS pada Bank Umum Syariah di Indonesia Selama Tahun 2015-2017 Sumber: Hasil Penelitian 2019 (Data diolah)}

Berdasarkan grafik diatas, dapat diketahui bahwa pengungkapan dari item-item GGBS selama tahun 2015-2017 dari sembilan bank umum syariah di Indonesia mengalami peningkatan secara berturut-turut yaitu 92\%, 92\% dan 93\%. Secara umum, bank umum syariah di Indonesia telah mengungkapkan 44 dari 47 item-item GGBS. Ada tiga item yang tidak diungkapkan sama sekali oleh BUS selama tahun 2015-2017, yaitu aspek GGBS yang belum diungkapkan sama sekali beserta alasannya, penjelasan ringkas mengenai mekanisme kerja direksi, dan pelaksanaan fungsi ombudsman untuk menampung masukan.

Hasil dari penelitian ini didukung oleh penelitian yang dilakukan oleh Jumansyah dan Syafei (2013) dan Holili (2017). Pada penelitian yang dilakukan oleh Jumansyah dan Syafei (2013), bank umum syariah telah mengungkakan penerapan good governance bisnis syariah sebesar 92,06\%. Sedangkan penelitian yang dilakukan oleh Holili (2017), selama tahun 2015-2017 bank umum syariah dalam mengungkapkan penerapan good governance bisnis syariah mengalami peningkatan dengan pengungkapan berturut-turut 70,56\%, 72,51\% dan 73,81\%.

Persaingan di dunia bisnis dan pertumbuhan perbankan syariah yang tumbuh pesat sejak tahun 1999, maka dibutuhkan suatu tata kelola perusahaan yang sesuai dengan ketentuan undang-undang serta ketentuan syariah. Tata 
Fredy Dwi Herlyanto: Analisis Penerapan Good Governance Bisnis Syariah Dalam Mencapai Maqashid Syariah pada Bank Umum Syariah di Indonesia

kelola perbankan syariah yang sesuai dengan ketentuan syariah diperlukan sebagai upaya mempertahankan kelangsungan usaha dengan tetap menerapkan bisnis yang berlandaskan akhlaqul karimah dalam setiap aspek dan kegiatan operasinya. Untuk menegakkan good governance bisnis syariah maka diperlukan suatu penciptaan suatu prakondisi secara spiritual maupun operasional yang didasarkan atas dasar taqwa serta adanya kerjasama dari empat pilar yaitu negara, ulama, pelaku bisnis dan juga dari masyarakat.

Selain untuk menjalankan bisnisnya yang berlandaskan ketentuan syariah, bank umum syariah juga wajib untuk mencapai dari tujuan syariah atau maqashid syariah. Hal ini bertujuan untuk menjaga keseimbangan dan kemaslahatan secara utuh. Berikut merupakan grafik rata-rata pencapaian maqashid syariah pada bank umum syariah di Indonesia selama tahun 2015-2017 dilihat dari pendidikan, keadilan, dan kemaslahatan:

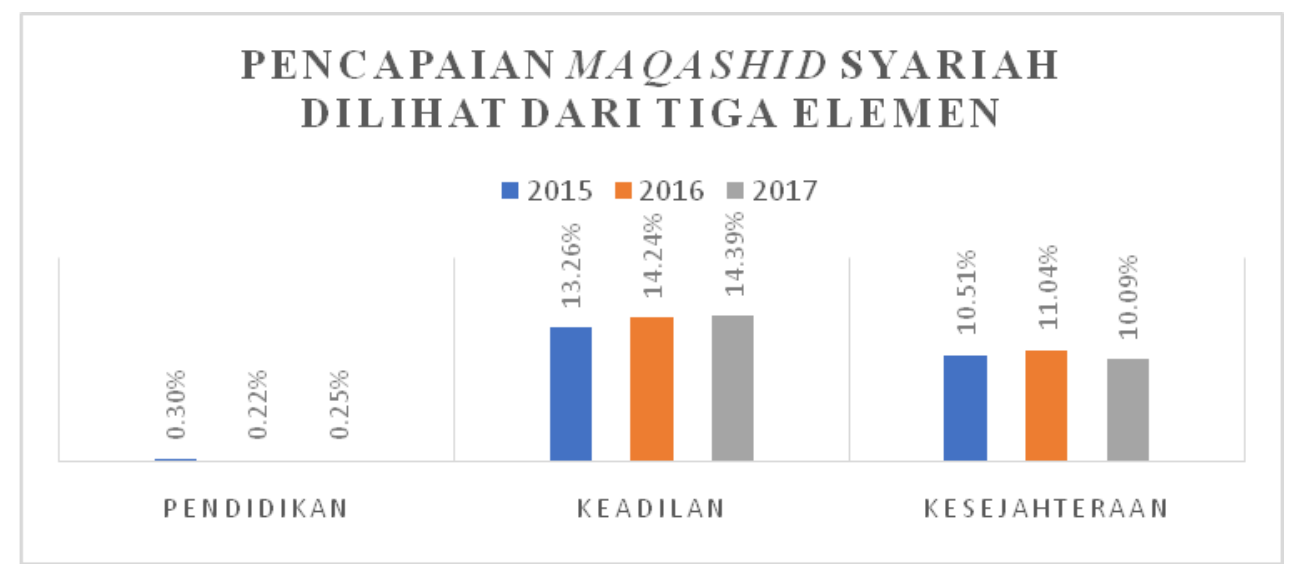

\section{Gambar 2. Rata-Rata Pencapaian Maqashid Syariah pada Bank Umum Syariah di Indonesia Selama Tahun 2015-2017 Sumber: Hasil Penelitian 2019 (data diolah)}

Berdasarkan grafik di atas, dapat kita ketahui bahwa kontribusi bank umum syariah dalam mencapai maqashid syariah pendidikan, dapat dilihat dari empat alokasi bank umum syariah dalam alokasi dana untuk pendidikan. Keempat alokasi tersebut yaitu bantuan pendidikan, penelitian, training, dan publikasi. Selama tahun 2015-2017, pencapaian bank umum syariah di Indonesia dalam hal pendidikan yaitu sebesar $0,30 \%, 0,22 \%$ dan $0,25 \%$.

Kontribusi bank umum syariah dalam menegakkan keadilan dapat dilihat dari tiga komponen yang dapat di lihat pada laporan keuangan bank. Ketiga komponen tersebut yaitu fair return, fair price, dan produk bebas bunga. Selama 
Fredy Dwi Herlyanto: Analisis Penerapan Good Governance Bisnis Syariah Dalam Mencapai Maqashid Syariah pada Bank Umum Syariah di Indonesia

tahun 2015-2017, kontribusi bank umum syariah dalam mencapai maqashid syariah berturut-turut $13,26 \%, 14,24 \%$ dan $14,39 \%$.

Jika dilihat dari pencapaian maqashid syariah bank umum syariah di Indonesia dalam meningkatkan kemaslahatan dapat dilihat dari profitabilitas, distribusi pendapatan melalui zakat dan investasi pada sektor rill. Secara ratarata, pencapaian bank umum syariah selama tahun 2015-2017 dalam meningkatkan kemaslahatan berturut-turut 10,51\%, 11,04\% dan 10,09\%.

Pencapaian bank umum syariah di Indonesia dalam mencapai maqashid syariah di Indonesia masih berfluktuatif. Berdasarkan grafik di atas total pencapaian maqashid syariah dilihat dari pendidikan, keadilan dan kesejahteraan selama tahun 2015-2017 berkisar 24,07\%, 25,50\% dan 24,73\%. Bank umum syariah sebagai perbankan yang kegiatan operasinya didasarkan pada ketentuan syariah selain bertanggung jawab pada kinerja keuangan, tetapi juga memiliki tanggung jawab terhadap kinerja non keuangan yang tercermin dalam maqashid syariah. Pencapaian bank umum syariah jika dilihat dari masingmasing komponen pencapaian maqashid syariah, tertinggi yaitu pada pencapaian keadilan. Holili (2017) dan Febriadi (2017) menyatakan bahwa implementasi bank umum syariah dalam mencapai maqashid syariah tercermin pada kegiatan operasional serta produk yang ditawarkan oleh bank.

Persaingan dalam dunia bisnis saat ini semakin ketat. Sebuah bisnis dalam menghadapi persaingan yang semakin ketat harus menerapkan good corporate governance dalam kegiatan operasinya (Ferial et al., 2016). Penerapan good corporate governance yang baik tidak hanya diperlukan untuk menghadapi situasi persaingan bisnis yang ketat, melainkan penerapan good corporate governance diperlukan untuk melindungi para stakeholder melihat adanya beberapa skandal dalam penyelewangan jabatan dalam manajemen (Rompas et al., 2018). Penerapan good governance yang baik dan sesuai dengan ketentuan syariah akan memberikan suatu budaya yang baik disegala bidang (Meilani, 2015). Maka Bank Indonesia selaku bank sentral mengeluarkan Peraturan Bank Indonesia No. 11/PBI/2009 tentang pedoman pelaksanaan good governance bisnis syariah bagi bank umum syariah dan unit usaha syariah.

Pemerintah Indonesia melalui Komite Nasional Kebijakan Governance pada tahun 2011 membentu suatu komite yang beranggotakan masyarakat ekonomi 
Fredy Dwi Herlyanto: Analisis Penerapan Good Governance Bisnis Syariah Dalam Mencapai Maqashid Syariah pada Bank Umum Syariah di Indonesia

syariah, Dewan Syariah Nasional Majelis Ulama Indonesia, dan Bank Indonesia membahas dan mengeluarkan kebijakan pelaksanaan good governance bisnis syariah. Hal ini dilatarbelakangi oleh keinginan agar terciptanya bisnis yang berlandaskan syariah yang didalam kegiatan operasinya mengedepankan akhalqul karimah dengan tercapainya maqashid syariah pada bank umum syariah. Selama tahun 2015-2017, Penerapan good governance bisnis syariah dalam rangka mencapai maqashid syariah masih berfluktuatif. Berikut merupakan grafik penerapan good governance bisnis syariah dan pencapaian maqashid syariah pada bank umum syariah di Indonesia tahun 2015-2017:

\section{PENERAPAN GOOD GOVERNANCE BISNIS SYARIAH DALAM MENCAPAI $M A Q A S H I D$ SYARIAH}

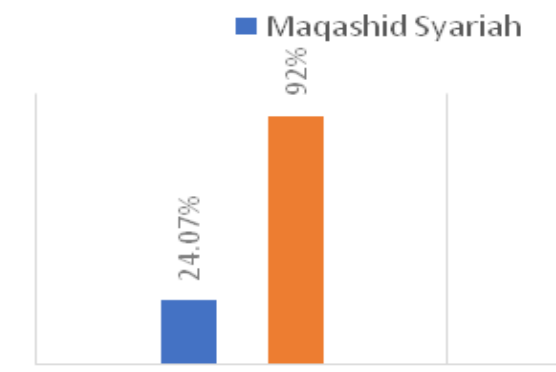

2015

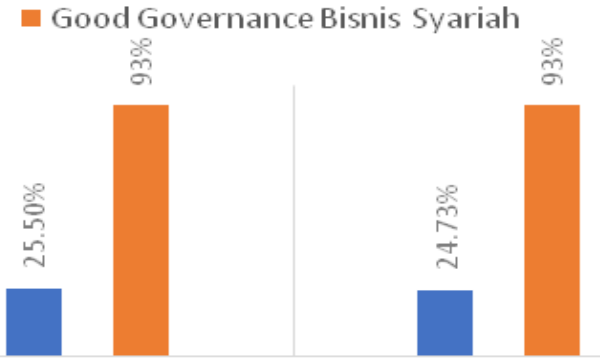

2016

\section{Gambar 3. Penerapan Good Governance Bisnis Syariah Dan Pencapaian Maqashid Syariah Pada Bank Umum Syariah Di Indonesia Tahun 2015-2017 Sumber: Hasil Penelitian 2019 (Data Diolah)}

Berdasarkan data diatas, dapat diketahui bahwa penerapan good governance bisnis syariah dalam mencapai maqashidsyariah pada bank umum syariah di Indonesia selama tahun 2015-2017 ialah masih berfluktuatif. Hal ini karena penerapan good governance bisnis syariah di Indonesia selama tahun 2015-2017 berturut-turut sebesar 92\%, 93\% dan 93\% dan pencapaian maqashidsyariah sebesar $24,07 \%, 25,50 \%$ dan 24,73\%. Jika dilihat berdasarkan ketiga tujuan syariah (maqashidsyariah) yaitu mendidik individu, menciptakan keadilan, dan kepentingan publik, peneliti menyimpulkan bahwa penerapan good governance bisnis syariah pada bank umum syariah di Indonesia bertujuan untuk menciptakan keadilan. Pernyataan ini didukung oleh Holili (2017) dan Febriadi (2017). 
Fredy Dwi Herlyanto: Analisis Penerapan Good Governance Bisnis Syariah Dalam Mencapai Maqashid Syariah pada Bank Umum Syariah di Indonesia

Penerapan good governance bisnis syariah merupakan upaya untuk mempertahankan pertumbuhan serta keberlangsungan usaha bank syariah. Selain sebagai upaya untuk mempertahankan keberlangsungan dan pertumbuhan usaha, good governance bisnis syariah digunakan untuk melindungi kepentingan stakeholder dengan menerapkan bisnis yang berdasarkan akhlaqul karimah dengan menciptakan serta memelihara kebaikan dengan tercapainya maqashidsyariah. Stakeholder theory menyatakan bahwa stakeholders merupakan individu atau sekelompok orang yang mampu dipengaruhi dan mempengaruhi tujuan suatu organisasi. Menurut peneliti, stakeholders atau pihak yang memiliki kepentingan terhadap bank umum syariah mayoritas merupakan pihak nasabah yang melakukan lalu lintas keuangan, baik menabung, berinvestasi, dan mengajukan pembiayaan. Maka, bank umum syariah wajib untuk menerapkan good governance bisnis syariah sebagai upaya untuk menjalankan bisnis syariah sesuai dengan ketentuan secara umum dan syariah yaitu transparansi, akuntabilitas, responsibilitas, independensi, dan kewajaran.

Penerapan good governance bisnis syariah sesuai dengan ketentuan syariah yang berlandaskan akhlaqul karimah dengan menjaga kepentingan stakeholders dengan memelihara kebaikan dengan tercapainya maqashidsyariah salah satunya yaitu menciptakan keadilan (Iqamah al-Adl). Dengan menerapkan good governance bisnis syariah maka bank umum syariah akan memperhatikan fair return, jasa dan produk yang terjangkau dan menjamin produk bebas bunga. Dengan diterapkannya penerapan good governance bisnis syariah maka akan menimbulkan kepercayaan dari stakeholders (para nasabah) dengan bank syariah. Febriadi (2017) menyatakan bahwa wujud implementasi maqashidsyariah tercermin dari kegiatan operasional bank dan produk-produk yang ditawarkan seperti deposito dan tabungan mudharabah, giro wadiah, pembiayaan mudharanah dan pembiayaan musyarakah.

\section{KESIMPULAN}

Selama tahun 2015-2017, rata-rata bank umum syariah di Indonesia telah mengungkapkan penerapan good governance bisnis syariah sebesar 93\% atau sebesar 44 item dari total 47 item yang harus diungkapkan. Item-tem yang tidak diungkapkan secara umum yaitu, aspek good governance bisnis syariah yang 
Fredy Dwi Herlyanto: Analisis Penerapan Good Governance Bisnis Syariah Dalam Mencapai Maqashid Syariah pada Bank Umum Syariah di Indonesia

belum dilaksanakan, mekanisme kerja dewan direksi beserta prosedur pendelegasian wewenang, dan melaksanakan fungsi ombudsman untuk menampung masukan bila terjadi penyimpangan.

Selama tahun 2015-2017, pencapaian maqashid syariah pada bank umum syariah di Indonesia masih berfluktuasi, yaitu sebesar 24\%, 26\% dan 25\%. Pencapaian maqashidsyariah bila dilihat dengan ketiga komponen maqashidsyariah yang meliputi mendidik individu, menegakkan keadilan, dan menghasilkan kemaslahatan, pencapaian maqashid syariah tertinggi yaitu menciptakan keadilan.

Penerapan good governance bisnis syariah sebesar 93\% belum berdampak terhadap pencapaian maqashidsyariah secara keseluruhan selama tahun 20152017. Namun, bila dilihat berdasarkan masing-masing tujuannya, penerapan good governance bisnis syariah akan berdampak terhadap pencapaian menciptakan keadilan.

\section{DAFTAR PUSTAKA}

Antonio, M. S., Y. D. Sanrego, dan M. Taufiq. 2012. "An Analysis Of Islamic Banking Performance: Maqashid Index Implementation in Indonesia and Jordania". Journal of Islamic Finance International Islamic University Malaysia, Vol. 1, No. 1, hlm: 12-29.

Febriadi, S. R. 2017. "Aplikasi MaqashidSyariah Dalam Bidang Perbankan Syariah". Jurnal Ekonomi dan Keuangan Syariah Universitas Islam Bandung, Vol. 1, No. 2, hlm: 231-245.

Ferial, F., Suhadak, dan S. R. Handayani. 2016. "Pengaruh Good Corporate Governance Terhadap Kinerja Keuangan dan Efeknya Terhadap Nilai Perusahaan". Jurnal Administrasi Bisnis Universitas Brawijaya, Vol. 33, No. 1, hlm: 146-153.

Holili, T. 2017. "Analisis Penerapan Good Governance Bisnis Syariah dan Pencapaian Kinerja Perbankan Syariah Indonesia Ditinjau dari Maqashid Shariah dan Profitabilitas". Jurnal akuntansi FEB Universitas Mataram, Vol. 1, No. 1, hlm: 1-13. 
Fredy Dwi Herlyanto: Analisis Penerapan Good Governance Bisnis Syariah Dalam Mencapai Maqashid Syariah pada Bank Umum Syariah di Indonesia

Jumansyah, dan A. W. Syafei. 2013. "Analisis Penerapan Good Governance Business Shariah dan Pencapaian Maqashid Shariah Bank Syariah di Indonesia". Jurnal Al-Azhar Indonesia Seri Pranata Sosial, Vol. 2, No. 1, hlm: 25-37.

Kelly, M. 2003. Four Ideas for Reforming Corporate Governance Post-Enron. BusinessEthics.https://www.utne.com/community/fourideasforreformingcorporat egovernancepost-enron. (Diakses tanggal 15 November 2018).

Kholid, M. N., dan A. Bachtiar. 2015. "Good Corporate Governance dan Kinerja Maqasid Syariah Bank Syariah di Indonesia". Jurnal Akuntansi dan Auditing Indonesia Universitas Islam Indonesia, Vol. 19, No. 2, hlm: 126-136.

Meilani, S. E. R. Year. "Hubungan Penerapan Good Governance Business Syariah Terhadap Islamicity Financial Performance Index Bank Syariah di Indonesia". Artikel dipresentasikan pada Prosiding Seminar Nasional and The $2^{\text {nd }}$ Call for Syariah Paper di Universitas Muhammadiyah Surakarta.

Mohammed, M. O., dan D. A. Razak. 2008. "The Performance Measures of Islamic Banking Based on the Maqashid Framework". Artikel dipresentasikan pada International Islamic University Malaysia International Accounting Conference 25 June 2008, di Putra Jaya Marriot.

Mohammed, M. O., dan F. M. Taib. 2015. "Developing Islamic Banking Performance Measures Based on Maqasid Al-Shari'ah Framework: Cases of 24 Selected Banks". Journal of Islamic Monetary and Finance, Vol. 1, No. 1, hlm: 55-77.

Muchlis, S., dan A. S. Sukirman. 2016. "Implementasi Maqashid Syariah Dalam Corporate Social Responsibility di PT Bank Muamalat Indonesia". Jurnal Akuntansi Multiparadigma, Vol. 7, No. 1, hlm: 120-130.

Mutia, E., dan N. Musfirah. 2017. "Pendekatan Maqashid Shariah Index Sebagai Pengukuran Kinerja Perbankan Syariah di Asia Tenggara". Jurnal Akuntansi dan Keuangan Indonesia, Vol. 14, No. 2, hlm: 181-201.

Muzlifah, E. 2013. "MaqashidSyariah Sebagai Paradigma Dasar Ekonomi Islam". Jurnal Ekonomi dan Hukum Islam, Vol. 3, No. 2, hlm: 73-93.

Novrianda, H., dan A. Shar. 2016. "Analisis Penerapan Good Corporate Governance Dalam Hubungannya Dengan Kinerja Keuangan Pada PT. Bank Rakyat Indonesia Syariah". Baabu Al-Ilmi, Vol. 1, No. 2, hlm: 94-106. 
Fredy Dwi Herlyanto: Analisis Penerapan Good Governance Bisnis Syariah Dalam Mencapai Maqashid Syariah pada Bank Umum Syariah di Indonesia

Primadhyta, S. 2017. "OJK: Praktik GCG Perusahaan Indonesia Masih Tertinggal". $\quad$ https://www.cnnindonesia.com/ekonomi/20170920070153-78242846/ojk-praktik-gcg-perusahaan-indonesia-masih-tertinggal(diakses tanggal 15 November 2018)

Rompas, S. A. C., S. Murni, dan I. S. Saerang. 2018. "Pengaruh Pengungkapan Corporate Governance dan Ukuran Perusahaan Terhadap Kinerja Keuangan Perbankan yang Terdaftar di Bursa Efek Indonesia 2012-2016". Jurnal EMBA, Vol. 6, No. 3, hlm: 1508-1517.

Salim, A. 2018. "Perbedaan Kinerja Keuangan Perbankan Sebelum dan Sesudah Penerapan Good Corporate Governance (GCG) Studi Kasus Pada Bank Syariah Mandiri". Ekomadania, Vol. 1, No. 2, hlm: 149-176. 